\title{
Pendampingan penyusunan Standar Operasional Prosedur pelayanan di Desa Petajen Kecamatan Bajubang Kabupaten Batang Hari
}

\author{
A. Zarkasi dan Riri Maria Fatriani* \\ Fakultas Ilmu Sosial dan Ilmu Politik, Universitas Jambi \\ * ririmariafatriani@unja.ac.id
}

\begin{abstract}
Abstrak. Standar Operasional Prosedur merupakan perwujudan ukuran standar pemberian pelayanan berkualitas kepada masyarakat dan merupakan bagian dari tugas pokok dan fungsi aparatur negara sebagai abdi masyarakat. Dalam proses penyediaan pelayanan maka diwajibkan untuk memiliki standar operasional prosedur pelayanan di masingmasing unit pelaksana. Pelayanan yang berkualitas, cepat, mudah, terjangkau dan terukur dapat meminimalisir penyimpangan dan penurunan kinerja dalam penyelenggara pelayanan. Kegiatan pengabdian ini telah memberikan pendampingan bagi aparatur pemerintah desa dalam menyusun standar operasional prosedur oleh tim pengabdian Program Studi Ilmu Pemerintahan Fakultas Ilmu Sosial dan Ilmu Politik Universitas Jambi. Metode pengabdian yang digunakan adalah metode ceramah, berdiskusi dengan menggunakan materi pengetahuan yang disiapkan serta praktik pembuatan standar pelayanan prosedur secara langsung didampingi oleh tim pengabdian. Lokasi kegiatan pengabdian kepada masyarakat ini dilakukan di Desa Petajen Kecamatan Bajubang Kabupaten Batang Hari Provinsi Jambi. Hasil evaluasi kegiatan menunjukkan bahwa seluruh aparatur desa sangat mengapresiasi dengan adanya kegiatan pendampingan pembuatan standar operasional prosedur. Hal ini diharapkan agar dapat lebih memaksimalkan pelayanan sehingga dapat mengarahkan masyarakat secara efektif, efisien, konsisten dan memenuhi standar.
\end{abstract}

Kata kunci: Batang Hari, standar operasional prosedur, pelayanan, pemerintah desa

Abstract. The Procedures Standard Operating is a manifestation of a standard measure of providing quality services to the community and part of the basic tasks and functions of the state apparatus as public servants. In the process of providing services, it is required to have standard operating procedures for services in each implementing unit. Quality, fast, easy, affordable and measurable services can minimize deviations and decrease performance in service providers. This dedication activity has provided assistance to village government apparatus in compiling standard operating procedures by the dedication team of the Government Science Study Program, Faculty of Social and Political Sciences, Jambi University. The service method used is the lecture method, discussion using the prepared knowledge material and the practice of making standard service procedures directly accompanied by the dedication team. The location of community service activities was carried out in the Petajen Village, Bajubang District, Batang Hari Regency, Jambi Province. The results of the activity evaluation show that all village apparatus are very appreciative of the existence of mentoring activities in making standard operating procedures. This is expected to be able to maximize the service so that it can direct the community effectively, efficiently, consistently and full fill the standards.

Keywords: Batang Hari, procedures of standard operating, service, village government

To cite this article: Zarkasi, A., \& R. M. Fatriani. 2019. Pendampingan Penyusunan Standar Operasional Prosedur Pelayanan Di Desa Petajen Kecamatan Bajubang Kabupaten Batang Hari. Unri Conference Series: Community Engagement 1: 14-20. https://doi.org/10.31258/unricsce.1.14-20

(C) 2019 Authors

Peer-review under responsibility of the organizing committee of Seminar Nasional Pemberdayaan Masyarakat 2019 


\section{PENDAHULUAN}

Dinamika pembangunan di segala bidang, termasuk pelayanan publik, kini sedang mengalami guncangan besar sebagai akibat terjadinya proses perubahan dalam berbagai dimensi, khususnya di bidang pemerintahan. Perubahan-perubahan tersebut juga dipengaruhi oleh perubahan struktur kepemimpinan di daerah yang semula bersifat sentralistik, saat ini menjadi desentralistik. Hal ini berdampak pada munculnya permasalahan yang tidak diperkirakan sebelumnya. Dalam kondisi seperti ini, kehadiran pemimpin yang mampu menggerakkan organisasinya sangat dibutuhkan untuk memberikan pelayanan kepada masyarakat secara memuaskan (Dwiyanto, 2010).

Pemberian pelayanan aparatur pemerintah kepada masyarakat merupakan perwujudan dari fungsi aparatur negara sebagai abdi masyarakat. Dalam proses penyediaan layanan pada kenyataannya masih banyak pelayanan yang tidak baik atau kurang bersifat transparan kepada masyarakat. Kasus-kasus yang berkaitan dengan buruknya pelayanan publik dapat ditemukan contohnya pada beberapa instansi, seperti mental aparat yang kurang simpatik, adanya korupsi, kolusi dan nepotisme. Kejadian tersebut akan mengakibatkan munculnya unsur biaya pelayanan yang tinggi dan tingkat kebocoran yang cukup mengkhawatirkan baik dalam kehidupan sosial maupun dalam kehidupan ekonomi (Ratminto, 2005). Jika kondisi seperti ini terus dibiarkan, maka akan menghambat pembangunan sosial, politik, ekonomi dan hukum. Maka dari itu diperlukan pengembangan sistem manajemen pelayanan yang memenuhi standar kepuasan pelayanan kepada masyarakat.

Dalam instruksi Presiden Nomor 1 Tahun 1995 tentang Penugasan kepada MENPAN untuk meningkatkan pelayanan umum, telah mewajibkan kepada semua lembaga pemerintah agar menyusun standar pelayanan publik. Selanjutnya UU Nomor 25 tahun 2009 tentang Pelayanan Publik menuntut agar setiap institusi penyelenggara negara, BUMN/BUMD termasuk swasta berkewajiban melaksanakan amanat Undang-Undang Pelayanan Publik tersebut. Dalam Pasal 8 UU No. 25/2009 disebutkan bahwa:

a. Organisasi penyelenggara berkewajiban menyelenggarakan pelayanan publik sesuai dengan tujuan pembentukan.

b. Penyelenggara pelayanan publik sebagaimana dimaksud pada ayat (1) sekurang-kurangnya meliputi pelaksanaan pelayanan, pengelolaan pengaduan masyarakat, pengelolaan informasi, pengawasan internal, penyuluhan kepada masyarakat dan pelayanan konsultasi.

c. Penyelenggara dan seluruh bagian organisasi penyelenggara bertanggungjawab atas ketidakmampuan, pelanggaran, dan kegagalan penyelenggaraan pelayanan.

Berdasarkan paparan diatas dapat terlihat bahwa standar pelayanan di masing-masing unit pelaksana teknis harus dibuat oleh masing-masing unit kerja. Tolok ukur yang dipergunakan sebagai pedoman penyelenggaraan pelayanan maksimal dan acuan penilaian kualitas pelayanan hanya dapat ditentukan apabila sudah ada standar pelayanan. Dalam rangka pelayanan yang berkualitas, cepat, mudah, terjangkau dan terukur, maka penerapan standar pelayanan berfungsi untuk meminimalisir terjadinya penyimpangan dan penurunan kinerja dalam penyelenggaraan pelayanan.

Pemberian pelayanan terbaik oleh aparat desa kepada masyarakat selaku pelanggan menjadi sangat penting untuk dikaji. Pemerintah desa sebagai unit penyelenggara pemerintahan yang paling dekat dengan masyarakat sudah selayaknya mencerminkan pemberian pelayanan yang maksimal (Dewi, 2014). Namun demikian, pada kenyataannya para aparat desa kurang profesional dalam pemberian pelayanan. Seringkali masyarakat harus menghadapi aparat yang tidak berada ditempat ketika harus memberikan pelayanan, pelayanan berbelit-belit dan kurang transparan. Oleh karena itu, dalam rangka mengembangkan kemampuan aparat desa dalam memberikan pelayanan publik, kegiatan Pengabdian Pada Masyarakat (PPM) kali ini memiliki nilai penting dalam mewujudkan pelayanan terbaik kepada masyarakat.

Desa Petajen Kecamatan Bajubang Kabupaten Batang Hari dipilih karena aparatur desa menginginkan adanya kerjasama PPM dengan Fakultas Ilmu Sosial dan Ilmu Politik Universitas Jambi dengan adanya inisiatif tersebut dapat mewujudkan upaya Pelayanan desa menjadi lebih konsisten dan efektif melalui kegiatan pendampingan pembuatan Standar Operasional Prosedur. Selain itu di Desa Petajen, sebagian besar masyarakat bermata pencaharian sebagai petani sedangkan aparat pemerintah Desa Petajen sebagian besar berpendidikan SLTA ke bawah. Dengan kondisi tersebut, pemahaman aparat tentang pelayanan terbaik yang harus diberikan kepada masyarakat selaku pihak yang harus diberi pelayanan juga tidak maksimal. Oleh karena itu Desa Petajen Kecamatan Bajubang Kabupaten Batang Hari khususnya aparat desa dan Badan Permusyawaratan Desa dipilih sebagai khalayak sasaran dalam kegiatan pengabdian kepada masyarakat ini. 


\section{Masalah}

Setelah dilakukan survey awal dan wawancara dengan Kepala Desa Petajen Kecamatan Bajubang, Permasalahan yang dapat diidentifikasi dalam penyelenggaraan pelayanan publik antara lain Pertama, masih rendahnya kesadaran aparatur penyelenggara pelayanan publik untuk memberikan pelayanan maksimal kepada masyarakat. Kedua, belum adanya alur pelayanan, standar waktu pelayanan, jenis pelayanan, tarif dasar pelayanan dan mekanisme pengaduan keluhan pelayanan. Ketiga, belum ada atau belum diterapkannya standar pelayanan minimal.

Untuk memperjelas permasalahan yang harus dipecahkan, maka dirumuskan permasalahan dalam kegiatan PPM adalah sebagai berikut:

1. Bagaimana upaya meningkatkan kesadaran aparat Desa Petajen Kecamatan Bajubang agar dapat memberikan pelayanan prima kepada masyarakat?

2. Bagaimana upaya mewujudkan prosedur dan Standar Operasional Prosedur di Desa Petajen Kecamatan Bajubang?

\section{METODE PENERAPAN}

Terkait permasalahan yang terjadi pada Kantor Desa Petajen (Mitra Pengabdian) sebagaimana telah diuraikan sebelumnya maka kegiatan pengabdian kepada masyarakat ini ditawarkan pada aparat Desa Petajen dan Badan Permusyawaratan Desa Petajen dengan metode pelaksanaan kegiatan sebagai berikut:

\section{Tahap Persiapan}

Dilaksanakan sebelum kegiatan diskusi oleh tim pengabdian bersama mitra, yang meliputi penyusunan jadwal agenda, modul materi pendampingan, persiapan sarana dan prasarana, koordinasi lapangan, sosialisasi dengan mengumpulkan pihak yang terlibat.

\section{Tahap Pelaksanaan}

Terdiri dari beberapa tahap yaitu pemberian materi dihari pertama mengenai pentingnya standar operasional prosedur sebagai pengetahuan awal, kemudian dihari kedua memulai pendampingan pelaksanaan pembuatan standar operasional prosedur dengan output rancangan standar operasional prosedur yang disusun sendiri oleh peserta kegiatan (mitra).

\section{Tahap Evaluasi}

Monitoring dilakukan setiap selesai tahapan (hari pertama dan hari kedua). Evaluasi dilakukan sejalan dengan monitoring sehingga jika ada kekeliruan dan kendala dapat segera diatasi..

\section{HASIL DAN KETERCAPAIAN SASARAN}

Pada bagian ini akan dijelaskan mengenai hasil yang sudah dicapai dalam rangka kegiatan pengabdian kepada masyarakat dengan judul "Pendampingan Penyusunan Standar Operasional Prosedur Pelayanan Di Desa Petajen Kecamatan Bajubang Kabupaten Batang Hari” yaitu:

Tabel 1. Jadwal Pelaksanaan Pengabdian kepada Masyarakat

\begin{tabular}{lll}
\hline Hari/Tanggal & Kegiatan & Pemateri \\
\hline Jumat/14 Juni 2019 & Sambutan & Ketua Tim (A.Zarkasi) \\
& $\begin{array}{l}\text { Ceramah (penyampaian Materi) dan berdiskusi } \\
\text { Materi: Standar Operasional Prosedur dalam kajian } \\
\text { pelayanan Publik }\end{array}$ & $\begin{array}{l}\text { A Zarkasi } \\
\text { Riri Maria Fatriani }\end{array}$ \\
& $\begin{array}{ll}\text { Pendampingan pembuatan Standar Operasional A Zarkasi } \\
\text { Sabtu/15 Juni 2019 }\end{array}$ & $\begin{array}{l}\text { Prosedur bersama mitra (Aparat Desa Petajen dan } \\
\text { Anggota Badan Permusyawaratan Desa) }\end{array}$ \\
\hline
\end{tabular}

Desa membutuhkan suatu pemerintahan untuk menata dan mengurus setiap hal yang berkaitan dengan pembangunan desa. Struktur Pemerintahan Desa terdiri dari beberapa tingkatan yang setiap tingkatannya memiliki porsinya sendiri. Pemerintah desa ditugaskan oleh pemerintah pusat untuk mengatur masyarakat pedesaan setempat berdasarkan dengan undang-undang yang ada demi mewujudkan pembangunan pemerintah diwilayah desa. Setiap desa dikepalai oleh seorang kepala desa yang dibantu oleh jajaran perangkat desa 
lainnya dalam mengurus setiap keperluan desa. Setiap jajaran memiliki fungsi dan tugasnya masing-masing. Dengan pembagian tugas diharapkan setiap jajaran bisa memaksimalkan kinerjanya.

Untuk memaksimalkan kinerja dalam melayani masyarakat desa, diperlukan sebuah pedoman baku yang mengutamakan pelayanan sebaik mungkin, dengan adanya pedoman tersebut diharapkan masyarakat mengetahui sebuah standar pelayanan dalam bentuk Standar Operasional Prosedur atau dikenal dengan SOP. Atas pertimbangan inilah maka wajib diterbitkan Standar Operasional Prosedur Pelayanan Dikantor Desa. Seperti yang telah dituangkan dalam Undang-Undang Nomor 25 Tahun 2009 tentang pelayanan publik menjelaskan standar pelayanan adalah tolok ukur yang dipergunakan sebagai pedoman penyelenggaraan pelayanan dan acuan penilaian kualitas pelayanan sebagai kewajiban dan janji penyelenggara kepada masyarakat dalam rangka pelayanan yang berkualitas, cepat, mudah terjangkau dan terukur. Berikut adalah tahapan penyusunan Standar Operasional Prosedur (SOP):

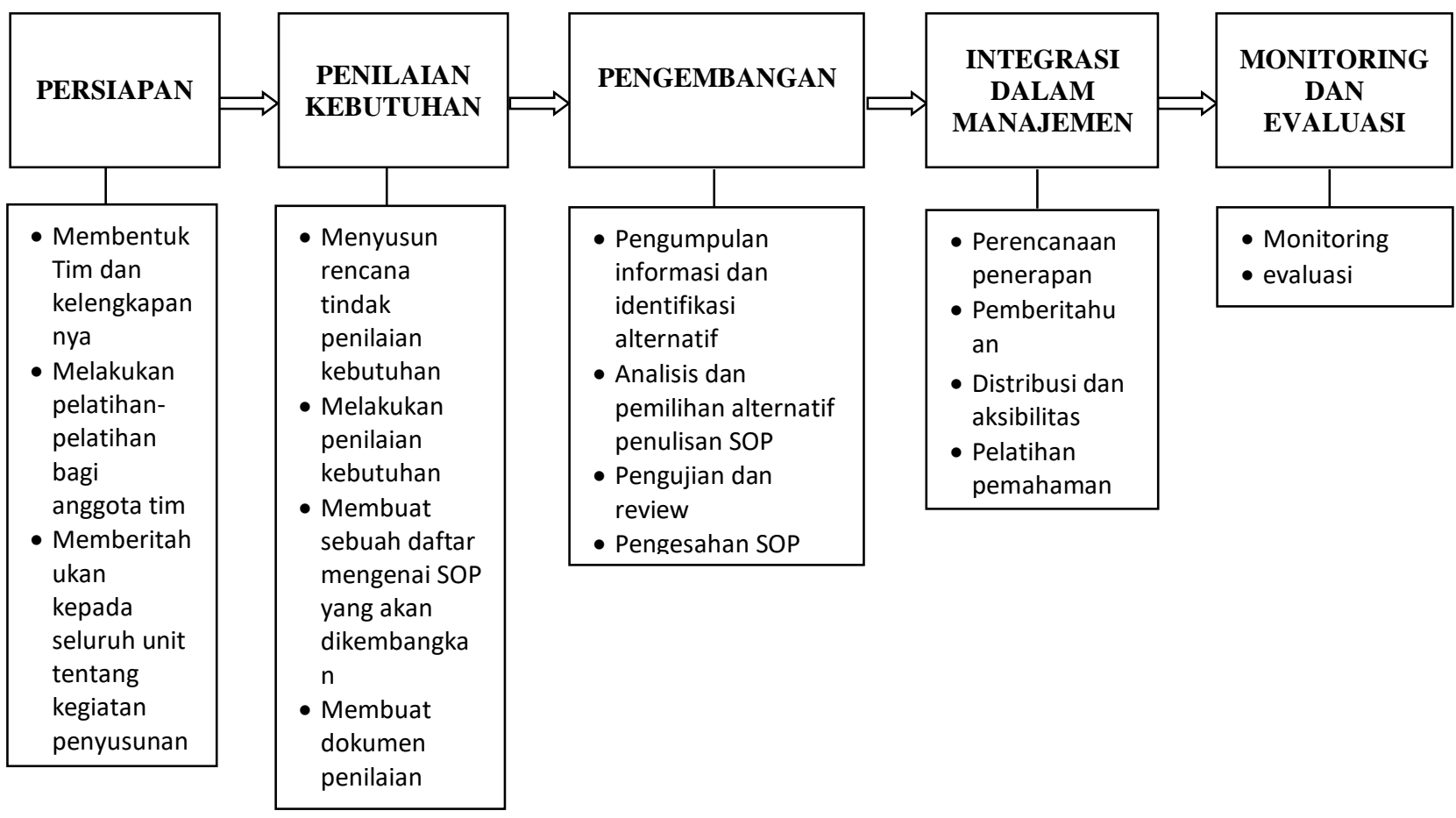

Gambar 1. Rincian Tahapan Penyusunan SOP

Dari gambar diatas keberhasilan tahapan-tahapan penyusunan SOP tersebut memerlukan pimpinan yang memiliki komitmen yang kuat terhadap organisasi, berkemauan, tegas dan menerima serta melakukan perubahan. Pimpinan merupakan actor inti perubahan (agent of change) yang akan menjadi panutan bagi seluruh pegawai yang menjadi bawahannya.

Adapun kegiatan dalam pengabdian kepada masyarakat mengenai pendampingan penyusunan Standar Operasional Prosedur sebagai berikut:

\section{Tahap Perencanaan Pengabdian}

Berdasarkan hasil social mapping yang dilakukan oleh Tim Pengabdian dari Fakultas Ilmu Sosial dan Ilmu Politik Universitas Jambi pada kegiatan yang akan dilaksanakan pada pengabdian ini, mulanya tim menganalisis mengenai kebutuhan akan kekurangan pemahaman Aparat Desa dan Badan Permusyawaratan Desa Petajen dalam hal penyusunan Standar Operasional Prosedur dan pentingnya Standar Operasional Prosedur ini di ketahui oleh masyarakat Desa Petajen Kecamatan Bajubang Kabupaten Batang Hari.

\section{Tahap Pelaksanaan Pengabdian}

Kegiatan ini dilakukan dengan metode ceramah yang disampaikan langsung oleh Tim Pengabdian secara bergantian dengan materi dipresentasikan lewat Power Point, video yang relevan mengenai pentingnya standar operasional prosedur. Materi pengabdian juga dijelaskan dari aspek pelayanan publik dan aturan-aturan wajib mengenai fungsi standar operasional prosedur dalam rangka pelayanan yang berkualitas, cepat, mudah dan terukur. 


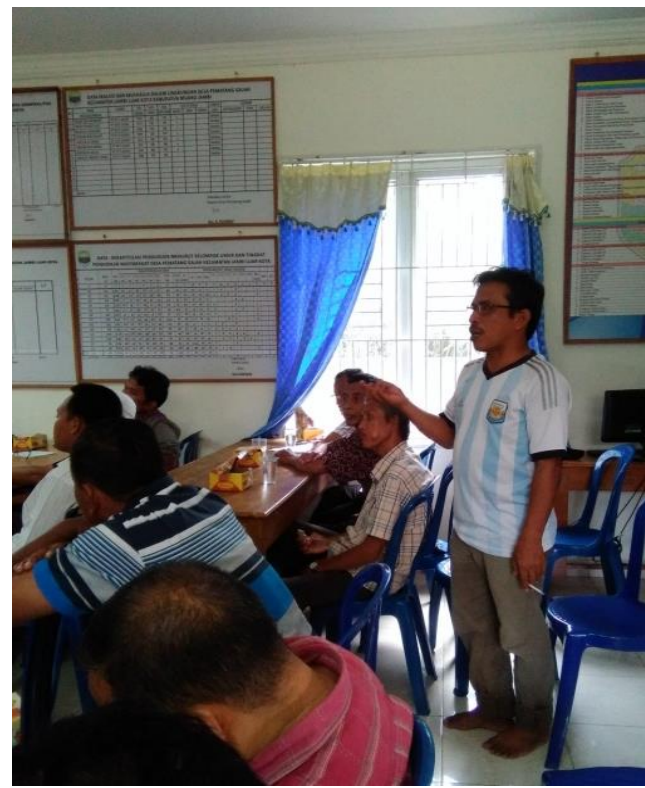

Gambar 2. Sesi tanya jawab

Dari penyampaian ceramah tersebut tolok ukur keberhasilannya dapat terlihat dari respon aparat desa dan anggota badan permusyawaratan desa petajen dalam sesi tanya jawab. Sesi tanya jawab itu mengungkapkan fakta bahwa selama ini terjadi kebingungan dari sisi masyarakat dan dari sisi aparat desa itu sendiri, karena tidak adanya standar operasional prosedur yang baku untuk dirujuk sebagai pelayanan yang berkualitas. Hal ini juga disebabkan rendahnya tingkat pendidikan aparat desa dan minimnya pengetahuan tentang standar pelayanan serta belum adanya sosialisasi dan pelatihan dari pemerintah tingkat kecamatan atau kabupaten mengenai SOP secara langsung.

\section{Tahap Evaluasi Kegiatan}

Adapun pada tahap evaluasi kegiatan pengabdian adalah sebagai berikut:

Tabel 2. Tolok ukur pelaksanaan

\begin{tabular}{lll}
\hline \multicolumn{1}{c}{ Tujuan } & \multicolumn{1}{c}{ Indikator Capaian } & \multicolumn{1}{c}{ Tolok Ukur } \\
\hline $\begin{array}{l}\text { Peserta memiliki pemahaman } \\
\text { arti penting mengenai Standar } \\
\begin{array}{l}\text { Operasional Prosedur (SOP) dan } \\
\text { tahap-tahap penyusunan SOP }\end{array}\end{array}$ & $\begin{array}{l}\text { Kesadaran peserta ada peningkatan } \\
\text { ditandai dengan respon dalam bentuk } \\
\text { Tanya jawab dan rasa ingin tahu } \\
\text { mengenai penyusunan SOP }\end{array}$ & $\begin{array}{l}\text { Peserta menyadari arti penting dari } \\
\text { Standar Operasional Prosedur dan } \\
\text { pelayanan berkualitas }\end{array}$ \\
$\begin{array}{l}\text { Peserta mampu menyusun } \\
\begin{array}{l}\text { Standar Operasional Prosedur } \\
\text { sesuai dengan ketentuan yang } \\
\text { diatur dalam permenpan dan } \\
\text { sesuai dengan landasan teori } \\
\text { pelayanan publik dengan } \\
\text { menyusun standar pelayanan } \\
\text { minimal }\end{array}\end{array}$ & $\begin{array}{l}\text { Aparat Pemerintah desa beserta } \\
\text { dengan Badan Permusyawaratan } \\
\text { Desa mampu merancang dan } \\
\text { menyusun sendiri Standar }\end{array}$ & $\begin{array}{l}\text { Operasional Prosedur sesuai dengan pendampingan yang dilakukan } \\
\text { standar minimal pelayanan }\end{array}$ \\
\hline
\end{tabular}

Berikut beberapa dokumentasi proses pendampingan penyusunan Standar Operasional Prosedur (SOP) di Kantor Desa Petajen Kecamatan Bajubang Kabupaten Batang Hari: 


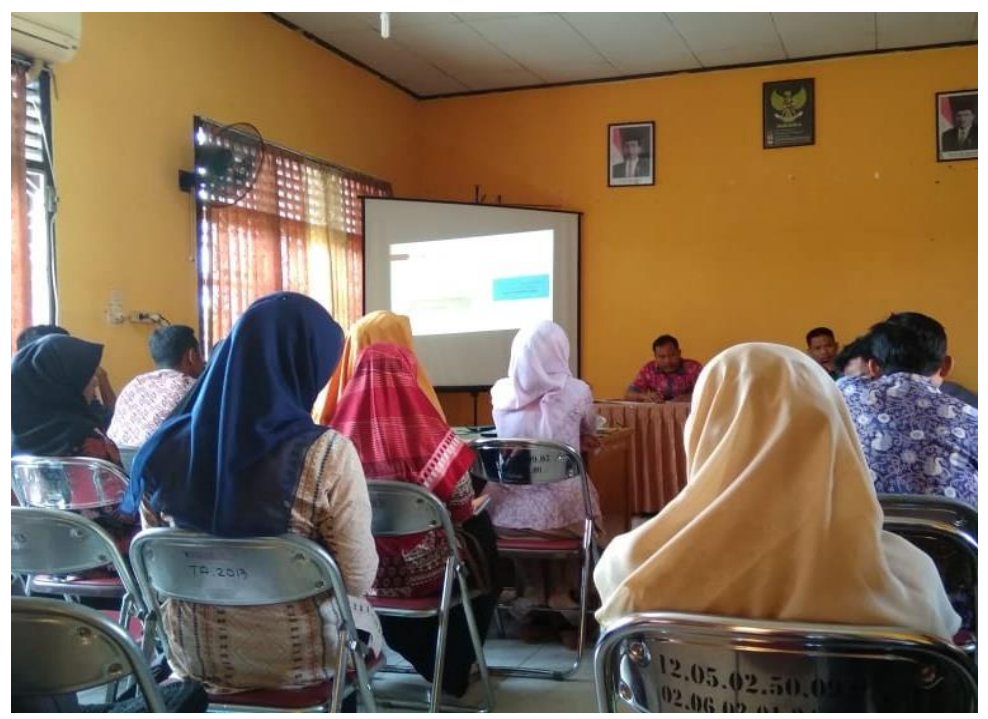

Gambar 3. Pendampingan pembuatan SOP dihari kedua

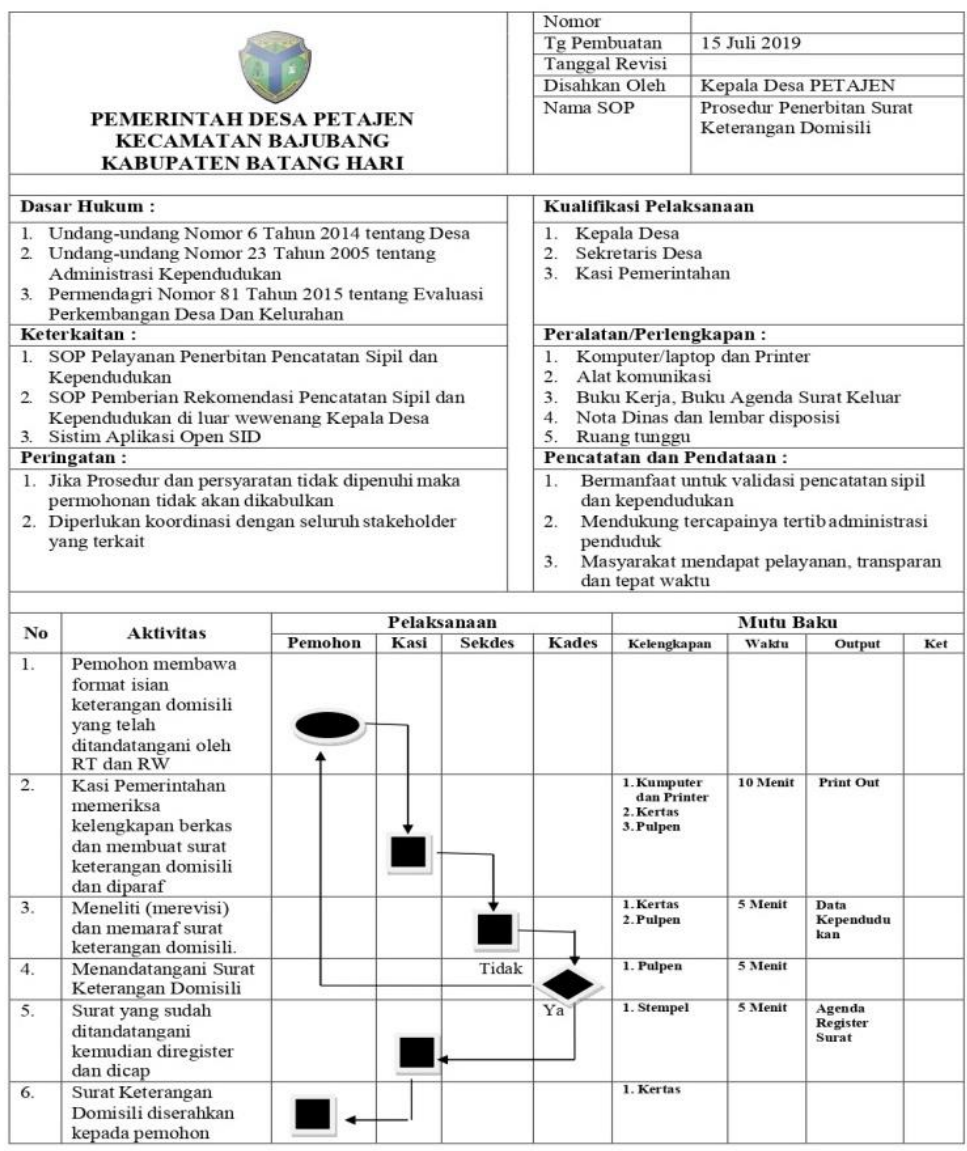

Gambar 4. Salah Satu Standar Operasional Prosedur hasil pendampingan

Salah satu Standar Operasional Prosedur (SOP) yang berhasil disusun bersama dengan aparat desa. Kegiatan pengabdian dapat terlaksana dengan baik karena adanya apresiasi yang tinggi ditandai dengan kerjasama yang baik, respon serta rasa ingin tahu lebih banyak mengetahui tahapan penyusunan Standar Operasional Prosedur. Hal ini membuktikan bahwa tingkat pendidikan yang rendah sekalipun menjadi aparat desa tidak menjadi kendala apabila memiliki komitmen yang kuat terhadap organisasi, berkemauan, tegas dan menerima serta melakukan perubahan. 


\section{KESIMPULAN}

Dengan adanya kegiatan pengabdian kepada masyarakat berupa pendampingan penyusunan Standar Operasional Prosedur, maka tentunya sudah menjadi kewajiban bagi pemerintah desa untuk memiliki sebuah standar baku yang menjadi ukuran serta komitmen kinerja aparat desa dalam melayani masyarakat. Standar Operasional Prosedur di kantor Desa dapat mempermudah masyarakat dalam mengetahui alur dari sebuah proses pelayanan dan hal ini juga termasuk salah satu proses transparansi dalam pelayanan publik. Standar Operasional Prosedur ini dapat meminimalisir tingkat kecurangan serta ketidakefektifan pelayanan dan juga perlu kiranya pimpinan dalam hal ini kepala desa terus dapat mengkatkan kapasitas diri, mengevaluasi pelayanan dan meningkatkan motivasi para pegawai tentang pentingnya pelayanan yang berkualitas, cepat, mudah dan terukur kepada masyarakat desa sehingga masyarakat tidak selalu beranggapan bahwa segala pengurusan yang berkaitan dengan pelayanan selalu berbelit-belit.

\section{UCAPAN TERIMA KASIH}

Atas terlaksananya kegiatan ini maka tim pengabdian kepada masyarakat sebagai pelaksana menyampaikan penghargaan dan ucapan terimakasih kepada Universitas Jambi sebagai pihak pemberi dana, LP3M Universitas Jambi, Kepala Desa Petajen, Seluruh Aparat Desa, Badan Permusyawaratan Desa Petajen dan Semua pihak yang telah membantu terlaksananya kegiatan pengabdian ini.

\section{DAFTAR PUSTAKA}

Dewi, U. 2014. Peningkatan Kapasitas Aparat Desa Timbulharjo Kecamatan Sewon Dalam Pemberian Pelayanan Prima kepada Masyarakat. Prosiding Seminar Nasional FIS UNY.

Dwiyanto, A. 2010. Manajemen Pelayanan Publik: Peduli, Inklusif dan Kolaboratif. Yogyakarta: Gadjah Mada University Press.

Peraturan Menteri Pendayagunaan Aparatur Negara dan Reformasi Birokrasi Republik Indonesia Nomor 35 Tahun 2012 tentang Pedoman Penyusunan Standar Operasional Prosedur Administrasi Pemerintahan.

Ratminto, \& A. S. Winarsih. 2005. Manajemen Pelayanan: Pengembangan Model Konseptual, Penerapan Citizen's Charter dan Standar Pelayanan Minimal. Yogyakarta: Pustaka Pelajar.

Undang-undang No. 25 Tahun 2009 tentang Pelayanan Publik. 